\title{
Improvement of Mathematics Learning Outcomes Build The Space Through Media Three Class 2 Student Dimensions SDN Palebon 02 Semarang
}

\author{
Nining Nur Syarifah \\ SD Negeri Palebon 02 Semarang \\ niningnursyarifah1980@gmail.com
}

\section{Article History \\ accepted 01/11/2020}

\begin{abstract}
Mathematics learning media is very necessary to support student learning outcomes. Threedimensional media can be used as an alternative solution for teaching space building materials. Three-dimensional media is a group of media without projection whose presentation is visually three-dimensional. This media group can take the form of an original object both living and dead, and can also be tangible as an imitation that represents the original (Santyasa, 2007: 15). The purpose of this study was to improve the quality of Mathematics learning material through the use of three dimensional media. This research is a classroom action research (PTK) which is conducted in two cycles, each cycle consisting of planning, implementation, observation, and reflection stages. The subjects of this study were 20 grade II students of SDN Palebon 02 Semarang, with a total of 20 students. The research instruments were observation sheets, learning test results and documentation. Data analysis includes data reduction, data presentation, and drawing conclusions. The finding of this research is that the use of Three Dimensional Media can improve the quality of students' Mathematics learning on Building Space material in class II SDN Palebon 02 Semarang. The results showed that the percentage of student learning activities in cycle I $74.5 \%$ increased in cycle II to $91.5 \%$ and the percentage of the number of students who completed the learning outcomes in cycle I $61.8 \%$ increased in cycle II to $100 \%$.
\end{abstract}

Keywords: learning quality, mathematics, three dimensional media

\begin{abstract}
Abstrak
Media pembelajaran matematika sangat diperlukan untuk menunjang hasil belajar siswa. Media tiga dimensi dapat dijadikan alternatif solusi untuk membelajarkan materi bangun ruang. Media tiga dimensi adalah sekelompok media tanpa proyeksi yang penyajiannya secara visual tiga dimensional. Kelompok media ini dapat berwujud sebagai benda asli baik hidup maupun mati, dan dapat pula berwujud sebagai tiruan yang mewakili aslinya (Santyasa, 2007: 15). Tujuan Penelitian ini adalah meningkatkan kualitas pembelajaran Matematika materi Bangun Ruang melalui penggunaan Media Tiga Dimensi. Penelitian ini merupakan penelitian tindakan kelas (PTK) yang dilaksanakan dalam dua siklus, tiap siklus terdiri dari tahap perencanaan, pelaksanaan, observasi, dan refleksi. Subjek penelitian ini adalah peserta didik kelas II SDN Palebon 02 Semarang yang berjumlah 20 peserta didik. Instrumen penelitian adalah lembar observasi, hasil tes belajar dan dokumentasi. Analisis data meliputi reduksi data, penyajian data, dan penarikan kesimpulan. Temuan penelitian ini adalah penggunaan Media Tiga Dimensi dapat meningkatkan kualitas pembelajaran Matematika peserta didik pada materi Bangun Ruang di kelas II SDN Palebon 02 Semarang. Hasil penelitian ditunjukkan dengan persentase aktivitas belajar siswa pada siklus I 74,5\% naik pada siklus II menjadi $91,5 \%$ dan persentase jumlah siswa yang tuntas dalam hasil belajar pada siklus I 61,8\% naik pada siklus II menjadi $100 \%$.

Kata kunci: kualitas pembelajaran, matematika, media tiga dimensi
\end{abstract}

Social, Humanities, and Education Studies (SHEs): Conference Series https://jurnal.uns.ac.id/shes

p-ISSN 2620-9284 e-ISSN 2620-9292 
SHEs: Conference Series 3 (3) (2020) 505- 511

\section{PENDAHULUAN}

Matematika merupakan salah satu mata pelajaran di sekolah dasar. Matematika termasuk sebagai ilmu dasar yang mendukung perkembangan ilmu pengetahuan dan teknologi lainnya. Pengalaman siswa belajar matematika sangat penting untuk memecahkan masalah dalam kehidupan sehari-hari. Mata pelajaran Matematika perlu diberikan kepada semua peserta didik mulai dari sekolah dasar untuk membekali peserta didik dengan kemampuan berpikir logis, analitis, sistematis, kritis, dan kreatif, serta kemampuan bekerjasama (BSNP, 2006: 147). Kompetensi tersebut diperlukan agar peserta didik dapat memiliki kemampuan memperoleh, mengelola, dan memanfaatkan informasi untuk bertahan hidup pada keadaan yang selalu berubah, tidak pasti, dan kompetitif.

Sekolah dasar sebagai awal pendidikan dasar mempunyai peran penting dalam memaknai konsep-konsep mata pelajaran. Pada pembelajaran matematika terdapat topik atau konsep prasyarat sebagai dasar untuk memahami topik atau konsep selanjutnya. Kesalahan dalam memaknai konsep akan berdampak pada proses pembelajaran pada jenjang selanjutnya.

Guru memegang peran sentral dalam mewujudkan keberhasilan pembelajaran. Yulisetiani (2015) mengungkapkan bahwa guru, sebagai fasilitator perlu menciptakan suasana apresiatif dan inspiratif di kelas. Untuk itu, guru harus senantiasa memiliki inovasi. Sebagai manajer pembelajaran di kelas guru berperan penting dalam pencapaian tujuan pembelajaran. Guru harus merancang perangkat pembelajaran yang efektif dan efisien dalam menunjang hasil belajar siswa.

Dalam merancang perangkat pembelajaran, guru harus memperhatikan tahap perkembangan peserta didik. Penggunaan strategi dan metode pembelajaran harus sesuai dengan karakteristik peserta didik. Peserta didik bukan hanya sebagai objek pembelajaran, tetapi juga sebagai subjek pembelajaran yang secara aktif berpartisipasi dalam proses pembelajaran. Penggunaan media pembelajaran yang tepat juga perlu diperhatikan. Dengan begitu, siswa akan mendapatkan hasil belajar yang optimal.

Pada kenyataannya, hasil belajar siswa kelas II SD N Palebon 02 pada mata pelajaran Matematika masih rendah. Berdasarkan data nilai ulangan harian siswa yang berjumlah 20 ditemukan bahwa hanya 10 siswa yang mengalami ketuntasan belajar. Jika dipersentasekan maka ketuntasan belajar siswa hanya 50\%. Rata-rata nilai ulangan harian siswa tersebut hanya mencapai 63 padahal Kriteria Ketuntasan Minimal (KKM) sebesar 70.

Rendahnya hasil belajar siswa ini disebabkan oleh beberapa hal. Pertama, penggunaan strategi dan metode yang digunakan guru kurang memperhatikan tahap perkembangan peserta didik. Dari pengamatan yang dilakukan, guru cenderung menjelaskan dengan berpegang pada buku. Pembelajaran yang dilakukan cenderung mendesain siswa untuk menghafal, bukan memahami konsep.

Guru tidak menggunakan benda-benda konkret yang ada di sekitar siswa sebagai media pembelajaran. Hal ini menyebabkan peserta didik kesulitan dalam memahami konsep yang diajarkan oleh guru. Menurut Piaget, anak usia sekolah dasar berada pada periode operasional konkret (Pitadjeng, 2006: 27). Pada periode ini, kemampuan berpikir anak terbatas pada benda-benda konkret. Anak masih membutuhkan bantuan memanipulasi obyek-obyek konkret untuk berpikir secara abstrak. Suatu konsep akan dipahami dengan baik oleh anak apabila direpresentasikan melalui benda-benda konkret ataupun pengalaman langsung.

Menurut Bruner (Pitadjeng, 2006: 29) ada tiga tahapan dalam membelajarkan matematika, yaitu tahap enaktif, tahap ikonik dan tahap simbolik. Pada tahap enaktif, anak belajar dengan menggunakan atau memanipulasi objek-objek konkret secara langsung. Pada tahap ikonik, pembelajaran direpresentasikan dalam bentuk bayangan visual yang merupakan manipulasi dari benda-benda konkret. Pada tahap simbolik, pembelajaran direpresentasikan dalam bentuk simbol-simbol matematis yang abstrak. Untuk menjembatani proses pembelajaran konkret menuju abstrak, maka dapat menggunakan media pembelajaran.

Penggunaan media pembelajaran yang menarik akan merangsang minat dan perhatian siswa dalam mengikuti proses pembelajaran bangun ruang. Selain itu, 
penggunaan media ini akan membantu siswa dalam memahami konsep dasar matematika. Apabila konsep dasar sudah dipahami, pastinya akan membantu meningkatkan hasil belajar siswa. Untuk itu, peneliti tertarik melakukan penelitian dengan judul "Peningkatan Hadil Belajar Matematika Bangun Ruang Melalui Penggunaan Media Tiga Dimensi pada Siswa Kelas II SD Palebon 02 Semarang".

Berdasarkan pembatasan masalah di atas, maka dapat dirumuskan suatu permasalahan sebagai berikut: Bagaimanakah peningkatan hasil belajar matematika materi bangun ruang melalui penggunaan media tiga dimensi pada siswa kelas II SD N Palebon 02 Semarang? Penelitian ini bertujuan untuk meningkatkan hasil belajar siswa kelas II SD N Palebon 02 materi bangun ruang melalui penggunaan media tiga dimensi.

\section{METODE}

Jenis penelitian ini adalah Penelitian Tindakan Kelas (PTK). Penelitian Tindakan Kelas (PTK) adalah penelitian yang dilakukan oleh guru di dalam kelasnya sendiri melalu refleksi diri, dengan tujuan untuk memperbaiki kinerjanya sebagai guru, sehingga proses pembelajaran dapat berjalan dengan baik dan hasil belajar siswa meningkat (Hamzah B. Uno dkk, 2011: 41). Sementara menurut Wina Sanjaya (2011: 26) PTK diartikan sebagai proses pengkajian masalah pembelajaran di dalam kelas melalui refleksi diri dalam upaya untuk memecahkan masalah tersebut dengan melakukan berbagai tindakan yang terencana dalam situasi nyata serta menganalisis setiap pengaruh dari perlakuan tersebut. Peneliti memilih metode penelitian tindakan kelas karena masalah yang ditemukan berkaitan dengan proses pembelajaran di kelas yaitu rendahnya hasil belajar kognitif pelajaran matematika materi bangun ruang pada siswa kelas II SD N Palebon 02. Proses tindakan yang dilakukan dalam penelitian ini diupayakan agar masalah dapat teratasi, sekaligus untuk meningkatkan kualitas pembelajaran. Terdapat berbagai pola dalam pelaksanaan PTK, yaitu pola guru peneliti, pola kolaboratif, dan pola simultan terintegrasi (Wina Sanjaya, 2011: 58). Penelitian Tindakan Kelas (PTK) ini menggunakan pola kolaboratif, yaitu penelitian dengan melakukan kolaborasi antara guru dan peneliti. Guru berperan dalam melaksanakan tindakan, sementara peneliti berperan sebagai pengamat. Teknik pengumpulan data yang digunakan pada penelitian ini adalah observasi, tes, dan dokumentasi. Suharsimi Arikunto (2009: 262) menyatakan bahwa analisis data penelitian ada dua macam yaitu analisis deskriptif kuantitatif dan deskriptif kualitatif. Deskriptif kuantitatif digunakan untuk menganalisis data yang berupa angka, sedangkan deskriptif kualitatif digunakan untuk menganalisis data yang berupa informasi berbentuk kalimat.

\section{HASIL DAN PEMBAHASAN}

Sebelum melakukan tindakan, peneliti melakukan pratindakan berupa pretest tentang bangun ruang kepada siswa kelas II SD N Palebon 02. Tes ini dilakukan untuk mengetahui tingkat pemahaman awal siswa tentang bangun ruang. Pretest dilakukan pada hari Kamis, 20 Oktober 2020 yang diikuti 10 siswa dari 20 siswa. Soal pretest terdiri dari 20 soal pilihan ganda. Berikut ini data hasil pretest siswa kelas II.

Tabel 1. Hasil belajar siswa pada kondisi awal Kondisi Awal

\begin{tabular}{|l|c|}
\hline \multicolumn{1}{|c|}{ Keterangan } & Kondisi awal \\
\hline Nilai tertinggi & 80 \\
\hline Nilai terendah & 43 \\
\hline Rata - rata Nilai & 59 \\
\hline Siswa belajar Tuntas & $25 \%$ \\
\hline Siswa belajar Belum Tuntas & $75 \%$ \\
\hline
\end{tabular}


Dari tabel di atas dapat dilihat bahwa nilai terendah yang diperoleh siswa adalah 43 , nilai tertinggi adalah 80 , dan rata-rata nilainya 63 , serta siswa yang telah belajar tuntas baru $36 \%$, maka masih banyak siswa yang belum mencapai nilai ketuntasan (KKM=70). Sehinga perlu diadakan tindakan untuk meningkatkan hasil belajar matematika pada umumnya, dan pada materi bangun ruang.

\section{Deskripsi Penelitian Siklus I}

Data yang diperoleh pada tahap pratindakan dijadikan acuan dalam melaksanakan tindakan pada siklus pertama dengan tujuan agar diperoleh suatu peningkatan hasil belajar siswa. Pada penelitian ini setiap siklus terdiri dari empat komponen yaitu perencanaan, pelaksanaan tindakan, observasi, dan refleksi. Perencanaan dilakukan dengan menyiapkan hal-hal yang dibutuhkan dalam melaksanakan tindakan pada proses pembelajaran bangun ruang. Pelaksanaan tindakan merupakan penerapan rancangan tindakan yang telah disusun berupa pembelajaran matematika dengan menggunakan media video animasi. Penelitian pada siklus I terdiri dari satu pertemuan. Pengamatan atau Observasi dilaksanakan selama proses pembelajaran berlangsung dengan menggunakan lembar observasi yang telah dibuat sebelumnya.

Tabel 2. Hasil belajar siswa pada Siklus I

\begin{tabular}{|l|c|}
\hline \multicolumn{1}{|c|}{ Keterangan } & Hasil Belajar siklus I \\
\hline Nilai tertinggi & 90 \\
\hline Nilai terendah & 55 \\
\hline Rata - rata Nilai & 73 \\
\hline Siswa belajar Tuntas & $43 \%$ \\
\hline Siswa belajar Belum Tuntas & $57 \%$ \\
\hline
\end{tabular}

Tabel 3. Perbandingan hasil tes kondisi awal dengan Siklus I

\begin{tabular}{|l|c|c|}
\hline \multicolumn{1}{|c|}{ Keterangan } & Kondisi awal & Hasil Belajar siklus \\
\hline Nilai tertinggi & 80 & 90 \\
\hline Nilai terendah & 43 & 55 \\
\hline Rata - rata Nilai & 59 & 73 \\
\hline Siswa belajar Tuntas & $25 \%$ & $43 \%$ \\
\hline Siswa belajar Belum Tuntas & $75 \%$ & $57 \%$ \\
\hline
\end{tabular}

Dari hasil analisa data peningkatan hasil belajar kognitif siswa siklus I dapat disimpulkan bahwa persentasi hasil belajar siswa yang tuntas naik dari $36 \%$ kondisi awal menjadi $63 \%$ setelah siklus I, berarti mengalami kenaikan sebesar $27 \%$, dengan nilai batas tuntas < 70. Adapun nilai terendah pada kondisi awal 43, sedangkan setelah siklus I mengalami kenaikan menjadi 55. Nilai tertinggi pada kondisi awal adalah 80 setelah siklus I menjadi 90. Rata-rata nilai pada kondisi awal 63 setelah siklus I menjadi 77,5. Pada siklus I ternyata masih ada siswa yang belum tuntas belajarnya sehingga guru berusaha untuk mengadakan perbaikan bagi siswa yang belum mencapai batas tuntas, dan memberikan pengayaan kepada 7 seluruh siswa yang sudah mencapai kriteria ketuntasan minimal (KKM = 70). Pelaksanaan Perbaikan dan Pengayaan ini dilaksanakan pada siklus II.

Refleksi yang dilakukan pada akhir siklus I bertujuan untuk mengetahui keberhasilan 
SHEs: Conference Series 3 (3) (2020) 505- 511

dari pembelajaran yang telah dilakukan. Dalam hal ini peneliti dan mitra peneliti melakukan diskusi untuk mengkaji kembali atau mengevaluasi data dan tindakan yang telah dilakukan pada siklus I sebagai upaya perbaikan pada siklus selanjutnya. Berdasarkan hasil observasi dan hasil tes pada siklus I, indikator keberhasilan belum tercapai. Ada beberapa hal yang harus diperbaiki. Hal ini dimaksudkan untuk memperbaiki pelaksanaan pembelajaran matematika menjelaskan ruas garis dengan menggunakan media video animasi agar dapat mencapai indikator keberhasilan yang telah ditentukan.

\section{Deskripsi Penelitian Siklus II}

Pada penelitian ini setiap siklus terdiri dari empat komponen yaitu perencanaan, pelaksanaan tindakan, observasi, dan refleksi. Secara rinci sajian siklus 2 adalah sebagai berikut: a. Perencanaan, Perencanaan dilakukan dengan menyiapkan hal-hal yang dibutuhkan dalam melaksanakan tindakan pada proses pembelajaran bangun ruang, diantaranya: 1) Peneliti dan guru menetapkan waktu pelaksanaan tindakan kelas, 2) Membuat RPP yang didesain sesuai dengan penerapan penggunaan media dalam pembelajaran bangun ruang, 3) Menyiapkan media pembelajaran yang akan digunakan dalam penelitian, yaitu media tiga dimensi berupa model bangun ruang, 4) Menyiapkan metode pembelajaran yang akan digunakan dalam penelitian, 5) Menyiapkan lembar observasi yang digunakan untuk mengamati aktivitas guru dan siswa selama proses pembelajaran, 6) Menyiapkan kamera untuk mendokumentasikan aktivitas guru dan siswa pada proses pembelajaran, 7) Menyiapkan evaluasi hasil belajar siswa yang digunakan pada akhir siklus. b. Pelaksanaan : Pelaksanaan tindakan merupakan penerapan rancangan tindakan yang telah disusun berupa pembelajaran matematika dengan menggunakan media tiga dimensi. Penelitian pada siklus II terdiri dari satu pertemuan. ( Kegiatan Awal, Kegiatan Inti dan Akhir ), c.Pengamatan : Observasi dilakukan oleh peneliti bekerjasama dengan mitra peneliti (teman sejawat). Teman sejawat yang bertindak mengamati aktivitas setiap siswa kelas II SD N Palebon 02. Dari hasil pelaksanaan perbaikan pembelajaran dan refleksi siklus II maka dapat disimpulkan bahwa pelaksanaan tindakan pembelajaran untuk meningkatkan hasil belajar siswa dalam kegiatan pembelajaran Matematika menjelaskan bangun ruang dapat diakhiri pada siklus II

Tabel 4. Hasil belajar siswa pada Siklus II

\begin{tabular}{|l|c|}
\hline \multicolumn{1}{|c|}{ Keterangan } & Hasil Belajar siklus II \\
\hline Nilai tertinggi & 100 \\
\hline Nilai terendah & 60 \\
\hline Rata - rata Nilai & 90 \\
\hline Siswa belajar Tuntas & $93,75 \%$ \\
\hline Siswa belajar Belum Tuntas & $0,06 \%$ \\
\hline
\end{tabular}

Tabel 4. Perbandingan hasil tes kondisi awal dengan Siklus I dan II

\begin{tabular}{|l|l|l|l|}
\hline Keterangan & $\begin{array}{l}\text { Kondisi } \\
\text { awal }\end{array}$ & $\begin{array}{l}\text { Hasil Belajar } \\
\text { siklus I }\end{array}$ & $\begin{array}{l}\text { Hasil Belajar } \\
\text { siklus II }\end{array}$ \\
\hline Nilai tertinggi & 80 & 90 & 100 \\
\hline Nilai terendah & 43 & 55 & 60 \\
\hline Rata - rata Nilai & 59 & 73 & 90 \\
\hline Siswa belajar Tuntas & $25 \%$ & $43 \%$ & $\begin{array}{l}93,75 \\
\%\end{array}$ \\
\hline
\end{tabular}


SHEs: Conference Series 3 (3) (2020) 505- 511

\begin{tabular}{|l|l|l|l|}
\hline Siswa belajar belum Tuntas & $75 \%$ & $57 \%$ & $0,06 \%$ \\
\hline
\end{tabular}

Dari hasil analisa data peningkatan hasil belajar kognitif siswa siklus 2 dapat disimpulkan bahwa persentsi hasil belajar siswa yang tuntas naik dari $43 \%$ kondisi awal menjadi $93,75 \%$ setelah siklus 2 , berarti mengalami kenaikan sebesar $51 \%$, dengan nilai batas tuntas $<70$. Adapun nilai terendah pada siklus 1 adalah 55 , sedangkan setelah siklus 2 mengalami kenaikan menjadi 60. Nilai tertinggi pada kondisi awal adalah 80 setelah siklus I menjadi 90, serta pada siklus 2 menjadi 100. Rata-rata nilai pada kondisi awal 63 setelah siklus I menjadi 73 dan pada siklus 2 menjadi 90. Hal itu menunjukkan bahwa hasil tindakan perbaikan pembelajaran pada tahap siklus II sudah ada peningkatan lebih besar dibandingkan dengan hasil pembelajaran pada siklus I karena hampir semua siswa nilainya sudah memenuhi KKM.

\section{SIMPULAN}

Berdasarkan penelitian tindakan kelas yang dilakukan di kelas II SD Negeri Palebon 02 Kecamatan Pedurungan Kota Semarang dapat disimpulkan bahwa penggunaan media tiga dimensi dapat meningkatkan hasil belajar Matematika materi Bangun Ruang. Peningkatan hasil belajar ditandai dengan nilai siswa yang mencapai KKM sebesar 70, yakni pada pra siklus nilai dari 16 siswa diketahui hanya $4(25 \%)$ siswa yang tuntas. Kemudian pada siklus I meningkat menjadi 8 (43\%) siswa yang tuntas. Pada siklus II mengalami peningkatan yaitu sebanyak 15 (94\%) siswa tuntas. Dari hasil penelitian tersebut, maka peneliti memberikan saran sebagai berikut: 1. Bagi Guru : a. Guru disarankan untuk memberikan motivasi belajar di dalam kegiatan belajar mengajar, sehingga saat pembelajaran siswa lebih antusias dan tertarik mengikuti pembelajaran, b. Dalam melaksanakan pembelajaran, guru disarankan untuk menggunakan media pembelajaran yang sesuai dengan tahap perkembangan siswa SD. Penggunaan media tiga dimensi dalam pembelajaran dapat membuat siswa senang dan cepat memahami materi segingga hasil belajar dapat meningkat, c. Saat menggunakan media pembelajaran sebaiknya guru juga memperhatikan faktor belajar yang lain untuk mendapatkan proses pembelajaran yang maksimal. 2. Bagi Sekolah : Sekolah diharapkan turut berperan dalam upaya meningkatkan hasil belajar siswa, misalnya dengan memberikan sarana dan prasarana yang memadai baik kepada guru atau pun siswa saat melakukan pembelajaran.

\section{DAFTAR PUSTAKA}

Adjie, Nahrowi dan Maulana. (2005). Geometri Datar dan Geometri Ruang.

Diakses dari http://file.upi.edu pada tanggal 14 Mei 2016 jam 20.10 WIB.

Arikunto, Suharsimi. (2003). Manajemen Penelitian. Jakarta: PT Rineka Cipta.

Arsyad, Azhar. (2011). Media Pembelajaran. Jakarta: Rajawali Pers.

BSNP. (2006). Standar Isi untuk Satuan Pendidikan Dasar dan Menengah.

Budiningsih, Asri. (2003). Belajar dan Pembelajaran. Yogyakarta: UNY Press.

Gunawan, Imam dan Anggarini Retno Palupi. (2012). Taksonomi Bloom - Revisi Ranah Kognitif: Kerangka Landasan untuk Pembelajaran, Pengajaran, dan Penilaian. Diakses dari e-journal.ikippgrimadiun.ac.id pada 14 Mei 2016 jam 19.03 WIB.

Heruman. (2008). Model Pembelajaran Matematika di Sekolah Dasar. Bandung:

Izzaty, Rita Eka, dkk. (2008). Perkembangan Peserta Didik. Yogyakarta: UNY Press.

Pitadjeng. (2006). Pembelajaran Matematika yang Menyenangkan. Jakarta:

Prihandoko, A. C. (2006). Memahami Konsep Matematika Secara Benar dan Menyajikannya

dengan Menarik. Jakarta: Departemen Pendidikan Nasional Direktorat Jenderal

Pendidikan Tinggi Direktorat Ketenagaan.

www.freewebs.com/santyasa/pdf2/MEDIA PEMBELAJARAN.pdf

Sugiyono. (2013). Metode Penelitian Pendidikan (Pendekatan Kuantitatif, Kualitatif, dan $R \& D)$. Bandung: Alfabeta. 
Suharjana, Agus. (2008). Pengenalan Bangun Ruang dan Sifat-Sifatnya di SD. Yogyakarta: Pusat Pengembangan dan Pemberdayaan Pendidik dan Tenaga Kependidikan Matematika.

Suharjo. (2006). Mengenal Pendidikan Sekolah Dasar Teori dan Praktek. Jakarta:

Departemen Pendidikan Nasional, Direktorat Pendidikan Tinggi, Direktorat Ketenagaan

Uno, Hamzah B., Nina Lamatenggo, \& Satria M. A. Koni. (2011). Menjadi Peneliti PTK yang Profesional. Jakarta: Bumi Aksara.

Yulisetiani, S. (2015). Kearifan Lokal sebagai Alternatif Bahan Ajar Kontekstual. Prosiding Seminar Nasional Adobsi. Universitas Sebelas Maret, 318-323. 
